\title{
The Effect of Giving Cold Therapy to Decreased Pain Sprain Ankle Basketball Players
}

\author{
Martha PASTARI ${ }^{1,2}$, Syokumawena ${ }^{1,2}$
}

\begin{abstract}
Astract
Sprain, is an injury to a joint that results in a torn ligament that functions as a binding between bones and as a stabilizer for the joint that occurs due to excessive pressure and sudden movements repeatedly. It is estimated that nearly 1.6 million injuries occur in connection with basketball in Indonesia. The epidemiology of injuries to male basketball players during training is 4.3 per 1000 while the competition is 9.9 per 1000 . This study is an experimental study with a Two Group Pre-Test and Post-Test Design. The research subjects were 30 permanent members of the Bangau Basketball Club which were divided into 2 groups: 01 group was a group that was given cold therapy before training alone, $\mathrm{O} 2$ group was a group that was given cold therapy after exercise alone. The study was conducted in October-November 2018. There was a difference between pain intensity and the degree of ankle sprain 01 group before and after exercise with the pain intensity difference test value of 0,000 and the value of the ankle sprain degree difference test result of $0.029(p<0.05)$. There was a difference between the intensity of pain and the degree of ankle sprain in the $\mathrm{O} 2$ group before and after exercise with the test value of the pain intensity difference of 0.024 and the value of the test result of the degree of ankle sprain difference of $0.047(p<0.05)$. Wilcoxon test results showed that there was an effect of cold therapy to reduce ankle sprain pain with $p<0.05$.
\end{abstract}

Keywords: heat therapy, cold therapy, sprain ankle.

\section{INTRODUCTION}

In United States there are more than 23.000 peoples per day, whether athlete or non athlete, that happen ankle injury. This incident is estimated 1 from 10.000 per day. Women athlete $25 \%$ has an incident rate more rather than men athlete. Then in Indonesia, it estimate almost 1.6 million injury occurring related with basket ball sport. Epidemiology injury in men players while exercise is 4,3 per 1000 while in league is 9,9 per 1000 (Haddar, 2015).
In Indonesia also has a injury casses that happen by people that doing a silat in contest category in POPDA Athlete East Java Nganjuk District in 2014 that shown swallow with percentage $37.24 \%$, scratched $18.11 \%$, hemorrhage $13.04 \%$, strain $10.87 \%$, sprain $17.93 \%$, fractur 5.97\% and dislocation 3.81\% (Yudi, 2014).

At school age, the risk that happen injury is nine times more higher while competing than while exercise. The injury is happen more than $60 \%$ in low extrimity, where the injury in ankle joint ligament is often happen both men or women. Based on mechanisme
${ }^{1}$ Faculty of Nursing, Health Polytechnic Public Health Ministry, Palembang, Indonesia

\section{Corresponding author.}

Martha PASTARI, Faculty of Nursing, Health Polytechnic Public Health Ministry, Palembang, Indonesia.

E-mail: marthapasta02@gmail.com 
occuring injury, physical contact that happen while in competency and exercise, it is called to men contact while competency more higher, around 52\%, than while exercise, $44 \%$, whereas on women, physical contact is occuring $46 \%$ while competing and $31 \%$ while exercise (Haddar, 2015).

Nowadays, high speed, physical contact and aggressiveness are a common thing that occurs to basket ball exercise, until causing the higher risk occurring injury. The injury that often happen to athlete is ankle sprain, which is injury to ligament that causing torn in ligament. Sprain happen because an excessive pressure and suddenly to joint or because excessive using that repeatedly. According to (American Collage of Emergency (AAOS), 2012) American College Health Association (ACHA) sprain is divided to Sprain mild (First Degree); usually accompanied with pain feeling, hematoma (inflammation) and decreasing function, Sprain Moderate (Second Degree); occur the infusion fluid that cause swollen and felt hot, then in Sprain Severe (Third Degree); all the entire ligament fibers break up cannot be moved as usual with severe pain, swelling, and the presence of blood in the joints. Basket ball player occur a trauma because Inversion Injury, where the players landing a leg and ankle is rotating (Nurjannah, 2016).

Based on the previous study that happen to research, there are a lot of extracurricular groups and basketball clubs among teenagers throughout the city of Palembang, South Sumatra Province, one of which is the Bangau Basketball Club „Bangau Sport Center” that located in Mayor Ruslan Street No 207 B RT 029 Urban Village 9 ilir District East Ilir III Palembang City. Bangau Basket Club „Bangau Sport Center” is the longest-running club, managed independently by youth groups who love basketball, actively participating in various tournaments at the City and National level, often getting awards, supported also that the effect of cold therapy on reducing ankle sprain pain has never been done on members of this basketball club, based on this, researchers are interested in examining „the effect of giving cold therapy through decreased pain sprain ankle to basket ball players".

\section{RESEARCH METHOD}

This research is experimental research with Two Group Pre-Test and Post-Test Design plan. The subject is divided into 2 groups there are: the groups $\mathrm{O} 1$ is group that given cold therapy before exercise only, group $\mathrm{O} 2$ is group that given cold therapy after exercise only. Intervention is given on fixed schedule exercise basket is do. Before and after exercise assessed the intensity of pain using Pain Tools Scale (Visual Analog Scale) and Sprain Ankle degree. There are the design table researches Two Group Pre-Test and Post-Test Design.

The subject research is divide into 2 groups there are: the $\mathrm{O} 1$ groups is the group that given cold therapy before exercise only, group $\mathrm{O} 2$ is group that given cold therapy after exercise only. Intervention is given to fixed schedule basket exercise do. Exercise before and after is assessed the intensity of the pain by using Pain Tools Scale (Visual Analog Scale) and sprain ankle degree. There are the research design tables Two Group Pre-Test and Post-Test Design.

\section{RESULT}

\section{DISCUSSION}

Based on the result, it can explains that the pain that experienced by group $\mathrm{O} 1$ basket player before exercise (pretest) is 15 people with mild intensity pain (50\%) and 15 people with moderate (50\%).

The result is in line with research of (Nurjannah, 2016), where the pain can be understand with different between individual, it depend on perception. Even though, any one differences about pain perception. In simple pain can be interpreted as a sensation that not fun whether sensory or emotional that related with any tissue damage or other factor.

Based on the research, it can get that pain experienced by group $\mathrm{O} 1$ basket ball player after exercise most of it is 27 people with mild pain intensity (90\%). The result is in the line with research. (Nurjannah, 2016), the Pain happen if any mechanical stimulation, thermal or chemistry that past certain stimuli of excitement. These stimuli are detected by nociceptors which are the

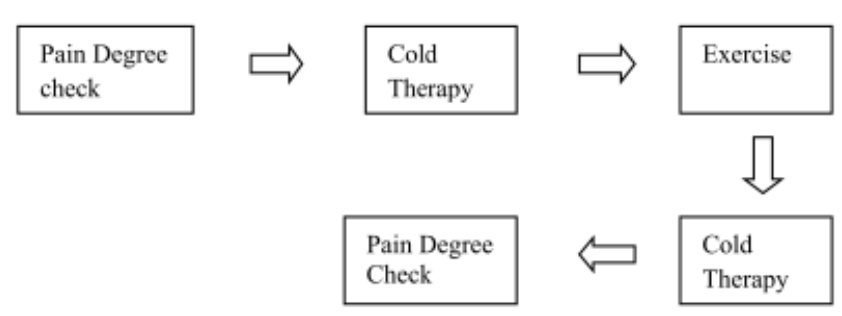

The illustration 2.13 Concept Framework 
The Effect of Giving Cold Therapy to Decreased Pain Sprain Ankle Basketball Players

Table 1. The result hypothesis test

\begin{tabular}{|l|l|l|l|}
\hline \multicolumn{1}{|c|}{ Group } & \multicolumn{1}{|c|}{ Data Sources } & \multicolumn{1}{c|}{$\begin{array}{c}\text { Wilcoxon Signed Ranks Test } \\
\text { (sig 2-Tailed) }\end{array}$} & \multicolumn{1}{c|}{ Result } \\
\hline \multirow{2}{*}{01} & Pain Intensity Before And After Exercise & 0.008 & Any effect \\
\cline { 2 - 5 } O2 & Sprain Ankle Degree before and after Exercise & 0.000 & Any effect \\
\cline { 2 - 5 } & Pain Intensity before and after Exercise & 0.000 & Any effect \\
\hline
\end{tabular}

free nerve endings. The stimulation will be carried as nerve impulses through Delta A fibers which myelinated, has fast delivery speed, and responsible to handle fast, sharp, and localized pain, and C fibers that are not myelinated with slow nerve speed and are responsible for painful blunt and not localized pain. The factors that related with causing pain is the conditions that causing injury whether Biology, Chemistry, Physical, or Psychology.

Based on the research, it can get that the part of sprain ankle degree that experienced by group $\mathrm{O} 1$ basket player before exercise is Degree I where ligament feels pain, it occur hematoma (hematoma) mild is 21 people (70\%). The result is in line with research of (Nurjannah, 2016), the injury can be happened because muscle coordination and not perfect joint, until causing the wrong moving and causing injury. This is can be happen because lack of warming up, lack of concentration or the condition of athlete in physical and mental is weak.

Based on the research, it is obtained that part of sprain ankle degree that experienced by group $\mathrm{O} 2$ basket player before exercise is 18 people with moderate pain intensity (60\%). Based on the research that done by (Hermawan, 2015). Sprain is an injury that related injury to ligament (tissue that connects bone to other bone) or joint capsule. The Severe damage on this joint it will cause the joint is become not stable. The symptom is causing a pain feeling, swollen, bruised, inflammation, instability and losing the ability to moving. But, the signs and symptom can be variation in intensity, it depends on the severity of the sprain.

Based on the research, it is obtained the pain that experienced by group $\mathrm{O} 2$ basket player after exercise as part of 23 people with mild pain intensity (76.7\%). Based on the research (Hermawan, 2015), sport injury can cause by internal factor and from external, this is like referring by Arif Setyawan (Hermawan, 2015) that exercise Injury between them it can cause by collision while in exercise or competency, weak muscle, overuse or facility and pre-facility that not good. The exercise that is causing injury sports is exercise (30\%), competency (35\%), sport class (20\%), and informal playing $(15 \%)$.

The result is showing that part of sprain ankle degree that experienced by group $\mathrm{O} 2$ basket player before exercise is Degree II where Ligament is felt hot and swollen is 16 people (53.3\%). According International Olympic Committee Medical Commission in Sport Medicine Manual that is quoted by (Hermawan, 2015). Based on the injury levels, the exercise is divided are 1). Higher risks sport, 2). Moderate risks sport, 3). Lower risks sport. The exercise that include moderate risks is; all the athletic exercise, including marathon running $30 \mathrm{~km}$ and walking $50 \mathrm{~km}$, badminton, baseball, basket ball, biathlon, bobsled and luge, cross country skiing, canoeing, rowing, softball, tennis outdoor.

The result research is showing that part of sprain ankle degree that experienced by group $\mathrm{O} 2$ basket player after exercise is Degree II where ligament is felt hot and swollen is 23 people (76.7\%). In line with the (Nurjannah, 2016) Research that Sprain is injury in joint that causing torn ligament that the function as binding between bones and as joint stability. This is happen because an excessive pressure and the moving is suddenly in repeatedly, where pain in swollen is usually mild into moderate and swelling that accompanies moderate to severe.. The injury is often experienced by basket players. This injury occurs when a player lands on the foot of another player or the ankle curls too out. While basket players playing, ankle injury is often happen while wrong landing jump shoot. Jump shoot that unstable will causing wrong landing position until the balance of the body while landing will causing ankle occur disposition. While this thing happen, the ligament can torn a half or entire.

The research is showing different intensity pain test is 0.000 and result of different ankle sprain degree test 
is 0.029 so this thing can be showed that both those value is $<0.05$, can be conclude that $\mathrm{H} 0$ is reject and $\mathrm{H} 1$ is accept are a differences between pain intensity or sprain ankle degree group $\mathrm{O} 1$ before and after exercise. Based on research (Atmojo, 2017), Ankle sprain occur because excessive pain (overstretching and hypermobility) or sudden inversion and plantar flexion trauma, while exercising, physical activity, while leg is not resting perfectly to the floor/ground until causing ligament structures to stretch beyond normal physiological and functional lengths. Elongation causes tearing of the lateral complex ligaments, this will cause pain when contracting. The pain causes immobility resulting in decreased muscle strength and limited mobility.

Then based in (Hermawan, 2015) Research ankle injury is caused by the pressure to make a sudden turning motion. Ankle injury can affect not only the side of the ankle but usually can also damage the outer (lateral) ligaments. With the support of a lot of nutrients and oxygen, metabolism at the site of injury will increase with the rest of the metabolism in the form of heat. That condition causes the location of the injured ankle area to be hotter (hot) compared to other locations that did not experience injury. Stacks of metabolic waste and other chemicals will stimulate nerve endings in the injured ankle and causing pain (dolor). This pain feeling is triggered by depressed nerve endings. Those inflammation signs symptoms will decrease the organ function or dislocation joint injury that called with the term joint decrease or functiolaesa.

The result is showing pain intensity difference test is 0.024 and sprain ankle degree different test is 0.47 so this thing is showing that those both values $<0.05$, can concluded $\mathrm{H} 0$ accepted and $\mathrm{H} 1$ rejected are a differences between pain intensity and sprain ankle degree group $\mathrm{O} 2$ before and after exercise.

Based on (Atmojo, 2017) research, ankle injury can be happen when sprained at suddenly continue with any response from body with inflammation signs that include from rubor (red), kalor (hot), tumor (swollen), dolor (pain), and functiolaesa (function decrease).

Then according to (Setiawan, 2011) research, causing exercise injury is usually from traumatic/collision in direct or exercise that repeatedly in a long time. This causing is divided into 1) external factor, is: (a) football, basket, boxing, karate; (b) exercise tools: stick hockey, racket, ball; (c) Field conditions: slippery, uneven, muddy; 2) internal factor, are: (a) anatomy factor. Unequal leg length, flat foot arch, tiptoe, so that when running it will interfere with movement; (b) Wrong movement/stroke exercises for example: backhand punch; (c) Muscle weakness; d) Low fitness level; 3) Overuse. Excessive and repetitive movements or exercises in a relatively long time/micro trauma that can cause injury.

\section{CONCLUSION}

\section{Analysis univariate Group 01}

1) Pain that experienced by group $\mathrm{O} 1$ basket players before exercise is 15 people with mild intensity pain (50\%) and 15 people with moderate intensity pain $(50 \%)$.

2) The pain that experienced by group $\mathrm{O} 1$ basket players after half of exercise is 27 people with mild intensity pain (90\%).

3) Half of sprain ankle degree that experienced group O1 basket player before exercise is I degree where the ligament is feels sick, become inflammation (hematoma) mild is 21 peoples (70\%).

4) Half of sprain ankle that experienced by group O1 basket player after exercise is I degree where ligament is feels sick, occur inflammation (hematoma) mild is 27 peoples (90\%).

\section{Analysis univariate Group 02}

1) Most of the pain that experienced by group $\mathrm{O} 2$ basket player before exercise is 18 peoples with moderate pain intensity is (60\%).

2) The pain that experienced by Group $\mathrm{O} 2$ basket players after exercise most of it is 23 peoples with mild pain intensity (76.7\%).

3) Most of it is sprain ankle degree experienced by group $\mathrm{O} 2$ basket player before exercise is Degree II where Ligament it felt hot and swollen is 16 people (53.3\%).

4) Most of it sprain ankle degree that experienced by group $\mathrm{O} 2$ basket player after exercise is Degree II where the Ligament is felt hot and swollen is 23 peoples $(76.7 \%)$.

\section{Analysis bivariate}

1) Pain intensity different test is 0.000 and the result of sprain ankle degree different test is 0.29 so this thing showing that those both values $<0.05$, can conclude $\mathrm{H} 0$ is rejected and $\mathrm{H} 1$ is accepted are a different between pain intensity and sprain ankle degree group $\mathrm{O} 1$ before and after exercise. 
2) Pain intensity different test is 0.024 and sprain ankle degree different test is 0,047 so this thing is showing that those both value $<0.05$, can be conclude $\mathrm{H} 0$ is accepted and $\mathrm{H} 1$ is rejected are a different between pain intensity and sprain ankle group $\mathrm{O} 2$ before and after exercise.

3) Based on the result of wilcoxon test to know is there any effect of giving cold therapy through sprain ankle pain decreased, it show that all the values is showing each variable comparison $<0.05$ is $0.008,0.000,0.000,0.000$ that means any effect giving cold therapy through sprain ankle pain decreased.

Compliance with ethics requirements: The authors declare no conflict of interest regarding this article. The authors declare that all the procedures and experiments of this study respect the ethical standards in the Helsinki Declaration of 1975, as revised in 2008(5), as well as the national law. Informed consent was obtained from all the patients included in the study.

\section{References}

1. American Collage of Emergency (AAOS) (2012) Pertolongan Pertama dan Pencegahan Cedera Olahraga. Jakarta: Erlangga.

2. Atmojo, W. T. (2017) Efektivitas Kombinasi Terapi Dingin dan Masase Dalam Penanganan Cedera Ankle Sprain Akut Pada Atlet Pencak Silat DIY. State University of Yogyakarta.

3. Haddar, D. (2015) Cedera Pada Pebasket. Available at: www.Orthopaeditrauma.blogspot.co.id (Accessed: 19 March 2018).

4. Hermawan, A. (2015) Presentase Cedera Olahraga Pada Atlet Sepak Bola Usia di Bawah 12 Tahun Dalam Kompetisi Sepak Bola Antar SSB Tingkat Nasional. State University of Yogyakar-

5. Nurjannah, S. (2016) Keefektifan Kombinasi Terapi Panas dan Dingin dengan Terapi Panas, Terapi Dingin Terhadap Cedera Otot Hamstring. State University of Yogyakarta.

6. Setiawan, A. (2011) 'Faktor Timbulnya Cedera Olahraga.', Jurnal Media IImu Keolahragaan Indonesia, 1(1). doi: https://doi. org/10.15294/miki.v1i1.1142.

7. Yudi, E. W. P. (2014) Identifikasi Cedera Pada Cabang Olahrga Pencak Silat Kategori Tanding Pada Atlet POPDA Kabupaten Nganjuk. State University of Yogyakarta. 
